Research Report No. 19/2009

\title{
Taxation, Corporate Social Responsibility and the Business Enterprise
}

Reuven S. Avi-Yonah

Follow this and additional works at: http:/ / digitalcommons.osgoode.yorku.ca/clpe

\section{Recommended Citation}

Avi-Yonah, Reuven S., "Taxation, Corporate Social Responsibility and the Business Enterprise" (2009). Comparative Research in Law \& Political Economy. Research Paper No. 19/2009.

http://digitalcommons.osgoode.yorku.ca/clpe/132 


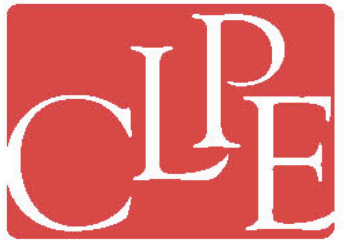

\section{Comparative Research in Law \& Political Economy}

CLPE RESEARCH PAPER 19/2009

\section{Reuven Avi-Yonah}

\section{Taxation, Corporate Social Responsibility and the Business Enterprise}

EDITORS: Peer Zumbansen (Osgoode Hall Law School, Toronto, Director, Comparative Research in Law and Political Economy, York University), John W. Cioffi (University of California at Riverside), Nassim Nasser (Osgoode Hall Law School, Toronto, Production Editor) 

CLPE Research Paper 19/2009

Vol. 05 No. 03 (2009)

Reuven Avi-Yonah

\title{
TAXATION, CORPORATE SOCIAL RESPONSIBILITY AND THE BUSINESS ENTERPRISE
}

\begin{abstract}
Under the aggregate or nexus of contracts view of the corporation, which is the dominant view among contemporary corporate scholars, corporate social responsibility (CSR) is an illegitimate attempt by managers to tax shareholders without their consent, and leads to managers being unaccountable to the shareholders that elected them. If so, management can be argued also to have a responsibility to maximize shareholder profits by minimizing corporate taxes as much as possible, and the state has no business in encouraging corporations to engage in illegitimate CSR through the tax system. This paper argues that both of these views, when taken to their extreme, are misguided. First, if corporations are not permitted to engage in CSR, then all social responsibility functions devolve on the state. Both taxing and spending become, to use Milton Friedman's language, purely governmental functions. But if corporate managers are required to minimize tax payments as much as possible, that could mean that the state is left without adequate resources to fulfill its governmental function. Thus, the aggregate view of the corporation, taken to its logical extreme, is self-defeating, because it could mean that neither corporations nor the government can fulfill their responsibilities to society. That is not an acceptable outcome. Second, even if from the perspective of management CSR is an illegitimate tax on shareholders, the government could still legitimately try to encourage corporations to engage in CSR by giving tax incentives. Assuming that some CSR activities are better performed by the private sector than by the government, it seems acceptable for the government to refrain from collecting certain amounts of tax in order to incentivize the private sector to engage in those activities. This is just as legitimate as the government taxing and then using is procurement muscle (paid for by the taxes) to encourage corporations to engage in CSR, as many governments have recently done.
\end{abstract}

Keywords: Corporate social responsibility, corporate tax, tax shelters

JEL classification: $\mathrm{H} 25$

\author{
Reuven S. Avi-Yonah \\ University of Michigan, \\ 625 S. State St. Ann Arbor MI 48109 USA \\ aviyonah@umich.edu
}




\title{
TAXATION, CORPORATE SOCIAL RESPONSIBILITY AND THE BUSINESS ENTERPRISE ${ }^{\circ}$
}

\author{
Reuven Avi-Yonah *
}

The imposition of taxes and the expenditure of tax proceeds are governmental functions... The whole justification for permitting the corporate executive to be selected by the stockholders is that the executive is an agent serving the interests of his principal. This justification disappears when the corporate executive imposes taxes and spends the proceeds for "social" purposes.

Milton Friedman ${ }^{1}$

\section{INTRODUCTION}

Should corporations pay tax?

The usual understanding of this question relates to the debate on whether there should be a corporate tax. Many observers have recently criticized the corporate tax, and some have

\footnotetext{
Irwin I. Cohn Professor of Law and Director, International Tax LLM, The University of Michigan. A previous version of this paper appeared as Corporate Social Responsibility and Strategic Tax Behavior, in Wolfgang Schoen (ed.), Tax and Corporate Governance, 183 (2008). I would like to thank David Hasen, Bob Kuttner, Sagit Leviner, Wolfgang Schoen, Dganit Sivan, Pekka Timmonen, and participants in workshops at Georgetown Law Center, the Interdisciplinary Center- Herzeliya, and the Max Planck Institute for Intellectual Property, Competition and Tax Law.

${ }^{*}$ Reuven S. Avi-Yonah, the Irwin I. Cohn Professor of Law and director of the International Tax LL.M. Program, specializes in international taxation and international law, and is widely published in these subject areas. He also served as consultant to the U.S. Treasury on tax competition and OECD on tax competition, and is a member of the Steering Group of the OECD's International Network for Tax Research and chair of the American Bar Association's Tax Section Committee on Consumption Taxes.

Professor Avi-Yonah earned his B.A., summa cum laude, from Hebrew University and then earned three degrees from Harvard: an A.M. in history, a Ph.D. in history, and a J.D., magna cum laude, from Harvard Law School. AviYonah has been a visiting professor of law at the University of Michigan, New York University, and the University of Pennsylvania. He has also served as an assistant professor of law at Harvard and as an assistant professor of history at Boston College. In addition, he has practiced law with Milbank, Tweed, Hadley \& McCloy, New York; Wachtell, Lipton, Rosen \& Katz, New York; and Ropes \& Gray, Boston. His research interests focus on various aspects of taxation and international law, but also on corporate governance and social responsibility.

${ }^{1}$ Milton Friedman, The Social Responsibility of Business Is To Increase Its Profits, NY Times SM17 (Sept. 13, 1970).
} 
defended it, but that is not the focus of this article. ${ }^{2}$ Instead, I will assume that the state wants to tax corporations, for whatever reason (a safe assumption, at least in the short to medium run). Given this assumption, I will address two questions. First, from the perspective of the corporation, should the corporation cooperate and pay the corporate tax, or should it engage in "strategic" tax behavior designed to minimize or eliminate its corporate tax burden? Second, from the perspective of the state, should the state use the corporate tax just to raise revenue, or should it also try to use it as a regulatory tool to steer corporate behavior in directions that it deems beneficial to society?

Both of these questions are related to the voluminous debate around corporate social responsibility (CSR). ${ }^{3}$ From the perspective of the corporation, if engaging in CSR is a legitimate corporate function, then corporations can also be expected to pay taxes to bolster society as part of their assumption of CSR. If, on the other hand, CSR is illegitimate, there is a question whether corporations should try to minimize their tax payments as part of avoiding CSR and maximizing the profits of their shareholders. From the perspective of the state, using tax as a tool to bolster CSR activity by corporations is arguably acceptable only if CSR is a legitimate corporate function.

The answer to these questions thus depends on our view of CSR. That view, in turn, depends on our view of the corporation. Historically, three views of the corporation have emerged and rotated in cyclical fashion. ${ }^{4}$ The first is the view that the corporation is primarily a creature of the state (the "artificial entity" view). The second is that the corporation is an entity separate from both the state and from its shareholders (the "real entity" view). The third is that the corporation is merely an aggregate of its individual members or shareholders (the "aggregate" or "nexus of contracts" view).

Each of these three views has different implications for the issue of tax and CSR. Under the artificial entity view, the corporation owes its existence to the state and is granted certain privileges in order to be able to fulfill functions that the state would like to achieve. Thus,

\footnotetext{
${ }^{2}$ For my view on this debate, as well as a review of the extensive literature, see Reuven S. Avi-Yonah, Corporations, Society and the State: A Defense of the Corporate Tax, 90 Va. L. Rev. 1193 (2004).

${ }^{3}$ For a review of this debate see Reuven S. Avi-Yonah, The Cyclical Transformations of the Corporate Form: A Historical Perspective on Corporate Social Responsibility, 30 Del. J. Corp. L. 767 (2005) and for previous literature see, e.g., Michael C. Jensen, Value Maximization, Stakeholder Theory, and the Corporate Objective Function, 12 Bus. Ethics Q. 235 (2002); see also Michael C. Jensen and William Meckling, The Theory of the Firm: Managerial Behavior, Agency Costs, and Ownership Structure, 3 J. Fin. Econ. 305 (1976). For different perspectives on CSR in general see also Michael J. Philips, Reappraising the Real Entity Theory of the Corporation, 21 Fla. St. U. L. Rev. 1061 (1994); C.A. Harwell Wells, The Cycles of Corporate Social Responsibility: An Historical Retrospective for the Twenty-first Century, 51 Kansas L. Rev. 77 (2002); William Allen, Our Schizophrenic Conception of the Business Corporation, 14 Cardozo L. Rev. 261 (1992); Cynthia A. Williams, Corporate Social Responsibility in an Era of Economic Globalization, 35 UC Davis L. Rev. 705 (2002); Ronald Chen and Jon Hanson, The Illusion of Law: The Legitimating Schemas of Modern Policy and Corporate Law, 103 Mich. L. Rev. 1 (2004)..

${ }^{4}$ See Avi-Yonah, Cyclical Transformations, supra.

${ }^{5}$ See Avi-Yonah, Cyclical Transformations, supra, and the literature cited therein.
} 


\section{9] TAXATION, CORPORATE SOCIAL ReSPONSibiLITY AND THE BusinesS ENTERPRISE 3}

engaging in some forms of CSR is part of the corporation's mission, and paying corporate tax is one way of fulfilling the corporation's CSR obligations. The state is fully justified in both imposing taxes on the corporation and in using the corporate tax as a regulatory device to steer corporate CSR activity.

Under the real entity view, the corporation is similar to an individual citizen in its rights and obligations. Just like an individual citizen does not have a legal requirement to aid her follow citizens but is praised if she does so, so the corporation may not be required to engage in CSR, but corporate management should be encouraged if they do so. As for taxes, just like an individual citizen, a corporation is legally required to pay taxes, and is expected not to engage in over-aggressive tax planning to minimize its tax obligations. The state may not require the corporation to engage in CSR, but is justified in encouraging corporations to do so and steering their efforts through the tax system.

The most interesting debate is under the aggregate or "nexus of contracts" view of the corporation, which is the dominant view among contemporary corporate scholars. ${ }^{6}$ Under this

\footnotetext{
${ }^{6}$ See, e.g., Kenneth J. Arrow, Social Responsibility and Economic Efficiency, 21 Pub. Policy 303, 303-07 (1973); Friedrich A. Hayek, The Corporation in a Democratic Society, in Whose Interest Ought It and Will It Be Run, in Management and Corporations (Melvin Anshen \& George L. Bach, eds., 1960), at 99; Friedman, supra. The classic case affirming this "shareholder primacy" doctrine is Dodge v. Ford Motor Co., 204 Mich. 459, 170 N.W. 688 (1919), at 507. See also the classic debate between Berle and Dodd (Adolph A. Berle, Corporate Powers as Powers in Trust, 44 Harv. L. Rev. 1049 (1931); Merrick Dodd, For Whom Are Corporate Managers Trustees, 45 Harv. Law Rev. 1145 (1932); Berle, For Whom Are Corporate Managers Trustees: A Note, 45 Harv. Law Rev. 1365 (1932).) The shareholder primacy doctrine has become a mainstay of modern corporate law. See, e.g. Henry Hansmann \& Reinier Kraakman, The End of History for Corporate Law, 89 Geo. L.J. 439, 441, 449-451 (2001) (shareholder primacy likely to dominate future development of corporate law); Frank H. Easterbrook and Daniel R. Fischel, the Economic Structure of Corporate Law 12 (1991) (stating that shareholders, as residual claimants, have implicitly contracted for promise that firm will maximize profits in long run); Henry G. Manne \& Henry C. Wallich, The Modern Corporation and Social Responsibility (1972) (noting that social responsibility of corporations is shareholder wealth maximizing); Bernard Black and Reinier Kraakman, A Self-Enforcing Model of Corporate Law, 109 Harv. L. Rev. 1911 (1996) (arguing that principal goal of corporate law is to maximize shareholder wealth);see also Michael Bradley, Cindy A. Schipani, Anant K. Sundaram and James P. Walsh, The Purposes and Accountability of the Corporation in Contemporary Society: Corporate Governance at a Crossroads, 62 Law \& Contemp. Probs. 9 (1999); Roberta Romano, The Political Economy of Takeover Statutes, 73 Va. L. Rev. 111, 113 (1987) (asserting that core goal of corporate law is to maximize equity share prices); ); Daniel J.H. Greenwood, Fictional Shareholders: For Whom Are Corporate Managers Trustees, Revisited, 69 S. Cal. L. Rev. 1021, 1023 (1996) ("[A]ll but the communitarians agree that virtually the sole task of corporate law is to ensure that managers act as agents for the shareholder owners."); cf. John C. Coffee, Jr., Unstable Coalitions: Corporate Governance As a Multi-Player Game, 78 Geo. L.J. 1495 (1990) (discussing role of stakeholders in firm); Lucian Bebchuk and Jesse Fried, Pay Without Performance (2004) (discussing need to align managerial incentives with shareholder interests). For arguments on the other side see Cynthia A. Williams, Corporate Social Responsibility in an Era of Economic Globalization, supra (it is debatable whether Hansmann and Kraakman's statement about shareholders' control of the corporation is accurate in the United States. In fact, one of the striking features of American corporate law is how little real control shareholders have, given that they are the "owners" of the corporation); Margaret M. Blair \& Lynn A. Stout, A Team Production Theory of Corporate Law, 85 Va. L. Rev. 247, 310 (1999) (where shareholders are widely dispersed, shareholders' voting rights are practically meaningless, given collective action problems,
} 
view CSR is an illegitimate attempt by managers to tax shareholders without their consent, and leads to managers being unaccountable to the shareholders that elected them. If so, management can be argued also to have a responsibility to maximize shareholder profits by minimizing corporate taxes as much as possible, and the state has no business in encouraging corporations to engage in illegitimate CSR through the tax system.

This article will argue that both of these views, when taken to their extreme, are misguided. First, if corporations are not permitted to engage in CSR, then all social responsibility functions devolve on the state. Both taxing and spending become, to use Milton Friedman's language, purely governmental functions. But if corporate managers are required to minimize tax payments as much as possible, that could mean that the state is left without adequate resources to fulfill its governmental function. Thus, the aggregate view of the corporation, taken to its logical extreme, is self-defeating, because it could mean that neither corporations nor the government can fulfill their responsibilities to society. That is not an acceptable outcome.

Second, even if from the perspective of management CSR is an illegitimate tax on shareholders, the government could still legitimately try to encourage corporations to engage in CSR by giving tax incentives. Assuming that some CSR activities are better performed by the private sector than by the government, it seems acceptable for the government to refrain from collecting certain amounts of tax in order to incentivize the private sector to engage in those activities. This is just as legitimate as the government taxing and then using is procurement muscle (paid for by the taxes) to encourage corporations to engage in CSR, as many governments have recently done. ${ }^{7}$

The following discussion is divided into four parts. Part II of the article briefly summarizes the development of the three views of the corporation. Part III applies these three views to the question whether corporations should seek to minimize their corporate tax. Part IV applies the same three views to the question whether the state should use tax as a vehicle for encouraging and steering corporate CSR. Part V concludes.

shareholders' rational apathy, and the power top managers exercise in nominating the candidates for the board and in otherwise shaping the voting agenda); Lawrence E. Mitchell, A Theoretical and Practical Framework for Enforcing Corporate Constituency Statutes, 70 Tex. L. Rev. 579, 630-43 (1992) (arguing that courts should modify corporate law to grant stakeholders standing to sue directors when the former are harmed by corporate action); Marleen A. O'Connor, The Human Capital Era: Reconceptualizing Corporate Law to Facilitate Labor-Management Cooperation, 78 Cornell L. Rev. 899, 936-65 (1993) (arguing that corporate law should be changed to encourage employee representation on the board and standing to sue); David Millon, Theories of the Corporation, 1990 Duke L.J. 201, 261-62 (praising case law that reaffirms directors' discretion to consider nonshareholder interests). See generally Progressive Corporate Law (Lawrence E. Mitchell ed., 1995) (surveying recent nontraditional approaches to corporate legal scholarship); Developments in the Law - Corporations and Society, Harvard Law Review, (2004), $2176-2177$.

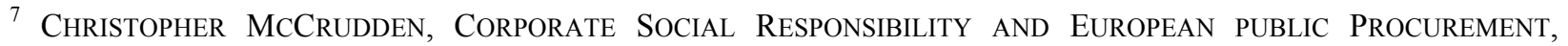
ForthComing in: Doreen MCBArnet, Aurora Voiculescu \& TOM CAMPBell (eds.), The NeW CORPORATE

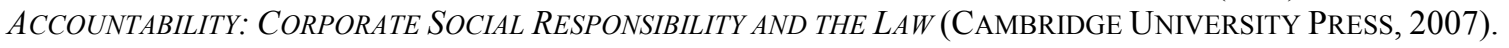




\section{THE THREE VIEWS OF THE CORPORATION: A HistoricAL PERSPECTIVE $^{8}$}

Historically, the corporation evolved from its origins in Roman law in a series of four major transformations. First, the concept of the corporation as a separate legal person from its owners or members had to be developed, and this development was only completed with the work of the civil law Commentators in the fourteenth century. By the end of the Middle Ages, the membership corporation, i.e., a corporation with several members who chose others to succeed them, had legal personality (the capacity to own property, sue and be sued, and even bear criminal responsibility) and unlimited life, was well established in both civil and common law jurisdictions. The next important step was the shift from non-profit membership corporations to for-profit business corporations, which took place in England and the U.S. in the end of the eighteenth and beginning of the nineteenth century. The third transformation was the shift from closely-held corporations to corporations whose shares are widely held and publicly traded, and with it the rise of limited liability and freedom to incorporate, which took place by the end of the nineteenth century and the beginning of the twentieth. Finally, the last major transformation was from corporations doing business in one country to multinational enterprises whose operations span the globe, which began after World War II and is still going on today.

Each of these four transformations (as well as a smaller, more temporary one which occurred in the U.S. in the 1980s with the advent of hostile takeovers) was accompanied by changes in the legal conception of the corporation. What is remarkable, however, is that throughout all these changes spanning two millennia, the same three theories of the corporation can be discerned. Those theories are the aggregate theory, which views the corporation as an aggregate of its members or shareholders; the artificial entity theory, which views the corporation as a creature of the state; and the real entity theory, which views the corporation as neither the sum of its owners nor an extension of the state, but as a separate entity controlled by its managers. ${ }^{9}$

\footnotetext{
${ }^{8}$ This part is based on Avi-Yonah, Cyclical Transformation, supra.

${ }^{9}$ These three theories are the standard ones in the literature. See, e.g., Millon, supra. For a full exposition of these developments see Avi-Yonah, Cyclical Transformations, supra.
} 
Each of these theories has different implications for the legitimacy of CSR, as indicated in the following table:

Table 1: Theories of the Corporation and CSR

\begin{tabular}{|c|c|c|c|}
\hline \multicolumn{2}{|l|}{$\begin{array}{l}\text { Theory } \\
\text { Type of CSR }\end{array}$} & Artificial & Real \\
\hline $\begin{array}{l}\text { For long-run benefit } \\
\text { of shareholders }\end{array}$ & Yes & Yes & Yes \\
\hline $\begin{array}{l}\text { Not for shareholders, } \\
\text { Corporation responsible }\end{array}$ & No & Yes & Yes \\
\hline $\begin{array}{l}\text { Not for shareholders, } \\
\text { Corporation not responsil }\end{array}$ & No & No & Yes \\
\hline
\end{tabular}

The first type of CSR involves activities that can clearly and demonstrably benefit shareholders in the long run. For example, actions that prevent environmental disasters or comply with legal and ethical rules can have a significant positive effect in preventing disastrous corporate calamities, even if they cost money in the short run. Thus, even proponents of the aggregate theory, the currently dominant theory of the corporation in academic circles, would support this type of CSR.

The second type of CSR involves activities that are designed to mitigate social harms the corporation was responsible for, even when there is no direct legal responsibility, and when no benefit to the shareholders can be shown. Under the aggregate theory, such activities should not be permitted because they do not benefit shareholders. But under the artificial entity theory, since it emphasizes the benefits of corporate existence derived from the state, an implicit contract can be inferred that the corporation will help the state in mitigating harms that it causes even in the absence of legal responsibility. Otherwise, the state will have to bear this burden imposed by the corporation it created.

Finally, the third type of CSR involves activities like AIDS prevention, for which the corporation is not responsible and which in most cases do not benefit its shareholders, even in the long run. This type of CSR would not be permitted under the aggregate or artificial entity theories. But under the real entity theory, since the corporation is regarded as a person just like individuals, it is permitted to act philanthropically just like individuals are, and should in fact be praised to the extent it does so. ${ }^{10}$ Thus, under the real theory, even CSR activities that have nothing to do with benefiting shareholders or with direct corporate responsibility are permitted.

\footnotetext{
${ }^{10}$ JB White, From Expectation to Experience: Essays on Law \& Legal Education (1999).
} 


\section{9] TAXation, Corporate social Responsibility AND the BusinesS ENTERPRISE 7}

The aggregate or nexus of contracts theory has been dominant in US academic circles in recent years, but less so elsewhere. To understand why, a comparative perspective is needed. Political economists distinguish among three types of advanced capitalist societies. Under the "varieties of capitalism" framework, economies can be differentiated by their comparative institutional advantages. In general, economies can be characterized as either liberal (market economies, such as the US and the UK), corporatist (organized market economies that rely on tightly integrated private and networked associations to resolve significant dilemmas of economic integration, such as Germany and Japan), or statist (depending on hierarchical solutions in resolving coordination problems, such as France). ${ }^{11}$

The varieties of capitalism framework suggest that firms in each of the three models of economic governance will distinguish themselves in different fields. In liberal market economies, the advantages of a flexible regulatory structure benefits industries targeting low costs and those operating in sectors characterized by radical innovation (e.g., software, bio technology). In corporatist economies, high levels of business coordination benefit sectors that rely on long-term contracts, and firms specialize in high quality, scale intensive and specialized supplier industries (autos, machine tools, chemicals). Statist economies favor large scale-intensive industries that have long time horizons or require major capital investment (autos, transport). ${ }^{12}$

There is an obvious correlation between the three varieties of capitalism described by political economists and the three historical theories of the firm outlined above. The liberal model of the UK and the US, with its emphasis on arm's length relationships and public trading, best first the aggregate theory of the firm. The statist, hierarchical model of France, with its emphasis on the relationship between the firm and the state, best fits the artificial entity model. And the German and Japanese style corporatist model best fits the real entity theory.

This relationship can also explain why in Europe CSR is much less controversial than in the US. Practically every EU government (including even the UK) has programs designed to foster CSR. ${ }^{13}$ These kind of programs are hard to imagine in the US context given the widespread hostility to CSR.

Fundamentally, therefore, the debate around CSR is linked to another wide-spread debate in corporate law: Whether corporate law is destined to "converge" on the US model of publicly traded corporations with dispersed share ownership, or whether other models (such as the

\footnotetext{
${ }^{11}$ Peter A. Hall and David Soskice (eds.), Varieties of Capitalism: The Institutional Foundations of Comparative Advantage (2001).

${ }^{12}$ Orfeo Fioretos, Varieties of Capitalism, Institutional Change, and Multilateralism in Post-War Europe (2004), 1112.

${ }^{13}$ European Commission, Corporate Social Responsibility: National Public Policy in the European Union (2004).
} 
German and Japanese models) are viable. The aggregate, nexus of contracts theory is closely linked to the US corporate governance model, while other models are much more open to CSR. Recent literature has given rise to doubts about the convergence hypothesis, but this debate will no doubt continue. ${ }^{14}$

As I have shown elsewhere, however, even in the US context the aggregate theory has not always been dominant. ${ }^{15}$ In fact, throughout most of the history described above, the real entity theory was the dominant one, and it can be argued that in practice most corporations are still operating on the basis of the real theory, not the aggregate one. Thus, CSR, which as we have seen is most easy to justify in all its forms on the basis of the real theory of the corporation, is likely to remain practiced for the future. The debate on CSR should therefore in my opinion shift from whether CSR is acceptable to how to make it more accountable and effective in obtaining social goals- but that is an issue for another day. ${ }^{16}$

\section{IMPLICATIONS OF THE THREE VIEWS FOR CSR AND THE CORPORATE TAX}

What are the implications of the three views of the corporation summarized above for the question with which we began, i.e., whether corporations should pay the corporate tax (assuming that a corporate tax is imposed)?

This is not just a theoretical question, because in fact corporations have significant leeway about whether they should pay the tax imposed on them. In the US, revenues from the corporate income tax amounted to about a quarter of all federal tax revenues in 1965; today the tax accounts for less than $10 \%$ of revenues and that number is declining. ${ }^{17}$ The major reason in recent years for this decline is the growth of a corporate tax shelter industry, in which some of America's best minds scour the Code for ways to reduce corporate tax liabilities by various transactions and then sell these transactions for high fees to corporate clients. ${ }^{18}$ Estimates of the

\footnotetext{
${ }^{14}$ Mark J. Roe, A Political Theory of American Corporate Finance, 91 Colum. L. Rev. 10 (1991); Lucian A. Bebchuk and Mark J. Roe, A Theory of Path Dependence in Corporate Ownership and Governance, 52 Stan. L. Rev. 127 (1999); Mark D. West, The Puzzling Divergence of Corporate Law: Evidence and Explanations from Japan and the United States, 150 U. Pa. L. Rev. 527 (2001).

${ }^{15}$ Avi-Yonah, Cyclical Transformations, supra.

${ }^{16}$ See James P. Walsh and Reuven S. Avi-Yonah, The Unfettered Corporation: Corporate Social Responsibility and the Coming Crisis of Corporate Control, forthcoming.

${ }^{17}$ Corporate tax rates were higher before 1986, but the base was narrower, so that the 1986 tax reform act (which reduced the rate from $46 \%$ to the current $35 \%$ ) actually raised taxes on corporations. However, the effective tax rates today are close to what they were before 1986. See Yin.

${ }^{18}$ See, e.g., Joseph Bankman, The New Market in Corporate Tax Shelters, 83 Tax Notes 1775 (1999); David A. Weisbach, The Failure of Disclosure as an Approach to Shelters, 54 SMU L. Rev. 73 (2001); George K. Yin, Getting Serious about Corporate Tax Shelters, 54 SMU L. Rev. 209 (2001).
} 


\section{9] TaXation, Corporate social Responsibility AND the Business ENTERprise 9}

revenue loss vary, but there is a consensus that it is significant and that the IRS has so far not been able to stop it with the weapons at hand. ${ }^{19}$

The decline in corporate tax revenues is even more pronounced on a world-wide basis, and especially among developing countries that have traditionally relied on the corporate tax for a much higher percentage of total revenues than OECD member countries. ${ }^{20}$ There are two likely reasons for this overall decline. The first is an increase in aggressive tax behavior among corporations, especially in the case of developing countries that lack the resources to effectively counter such strategic tax planning behavior, such as abusive transfer pricing. The second is tax competition among countries to attract corporate investments, which has grown significantly in the last two decades. ${ }^{21}$ This competition enables companies like Intel to pay no tax at all on its non-US income. The most recent manifestation of this trend has been inversion transactions, in which US-based corporations nominally move their headquarters to a tax haven like Bermuda. This type of transaction can result in a dramatic decrease in worldwide effective tax rates for the inverting corporation. ${ }^{22}$

In what follows, we will discuss the implications of each of the three views of the corporation for the attitude that the corporation should take to paying the corporate tax.

\section{A. The Artificial Entity VieW.}

From the artificial entity view the corporation is a creature of the state. The state creates it and bestows various legal advantages on it, such as legal personality and limited liability. The state

\footnotetext{
${ }^{19}$ The litigation record is mixed- see ACM Partnership v. Comm'r, 157 F.3d 231 ( ${ }^{\text {rd }}$ Cir. 1998); Compaq v. Comm'r, 277 F.3d 778 (5 ${ }^{\text {th }}$ Cir. 2001); UPS v. Comm'r, 254 F.3d $1014\left(11^{\text {th }}\right.$ Cir. 23001).

${ }^{20}$ In developing countries the corporate tax can amount to as much as $25 \%$ of total tax revenues, see World Bank, Tax Policy Handbook 165 (Parthasarathi Shome ed., 1995). The average from 1990 to 2001 was 17\%, as opposed to $7 \%$ in developed countries: Michael Keen and Alejandro Simone, Is Tax Competition Harming Developing Countries More Than Developed? 34 Tax Notes Int'l 1317 (2004). Keen and Simone show that from 1990 to 2001 corporate tax rates have declined in both developed and developing countries. However, while in developed countries this decline in the rates was matched by a broadening of the tax base, so that no decline in revenues can be observed, in developing countries the same period witnessed a decline of corporate tax revenues by about 20 percent on average.

${ }^{21}$ Reuven S. Avi-Yonah, Globalization, Tax Competition, and the Fiscal Crisis of the Welfare State, 113 Harv. L. Rev. 1573 (2000); Julie Roin, Competition and Evasion: Another Perspective on International Tax Competition, 89 Geo. L.J. 543 (2001).

${ }^{22}$ Reuven S. Avi-Yonah, For Haven's Sake: Reflections on Inversion Transactions, 95 Tax Notes 1793 (June 17, 2002)
} 
also creates the conditions for the corporation to operate in the market by providing defense and a property rights regime, as well as building infrastructure and educating workers.

The implication of this view for CSR, as noted above, is that the corporation is obligated not to impose additional burdens on the state that created it. Thus, to the extent the corporation's own activities result in additional burdens (e.g., by creating pollution), the corporation is obligated to remedy that situation.

It is less clear that the artificial entity view requires or permits corporations to engage in CSR that is unrelated to their activities. While historically the state created corporations "imbued with a public purpose", developments since the mid- $19^{\text {th }}$ century (such as general incorporation and the decline of ultra vires) have led to the view that the corporation fulfills its purpose sufficiently in engaging in its normal for profit activities, and should not be required to do more.

However, precisely that limitation also has implications for the corporate tax. To the extent the corporation is free to pursue purely for profit activities, as long as those do not impose a burden on the state, the state is left with the obligation to carry to weight of social responsibility on its own. For example, if there is a health crisis that the corporation did not contribute to creating, such as AIDS, the state and not the corporation has the obligation to address it. But this means that the state needs resources, and a major way of obtaining these resources is to impose taxes, including the corporate tax.

I would therefore argue that under the artificial entity view corporations have an affirmative obligation not to engage in aggressive tax planning designed to reduce their tax burden. The state created the corporation and the conditions for its operation in the market. In return, the state may legitimately expect corporations not to impose additional burdens on it. But since the state and not the corporation bears the burden of most social obligations under this model, the state can also expect the corporation to contribute its fair share to the ability of the state to fulfill its obligations to its citizens. This means that when the corporation engages in aggressive tax planning such as corporate tax shelters or abusive transfer pricing, it is breaching an implicit bargain with the state that created it, gave it legal rights, and created the conditions for it to make those same profits it is attempting to shield from tax.

Of course, this begs the question of how to distinguish abusive tax evasion from legitimate tax avoidance. But while this is a hard question to answer from the government's perspective, or in a court of law, it is less unclear from the corporation's perspective. Most corporate tax managers know very well when a transaction is tax motivated as opposed to having a non-tax business reason. Thus, a corporation can be legitimately expected to police its own behavior in this regard, without worrying too much about where the line should be drawn. ${ }^{23}$

\footnotetext{
${ }^{23}$ The exception would be tax competition, which can be argued represents legitimate business planning from the corporation's perspective.
} 


\section{9] TAXation, Corporate social Responsibility AND the Business ENTERpRise 11}

\section{B. THE REAL ENTITY VIEW.}

Under the real entity view, the corporation is similar to an individual. It is an entity made up of people (corporate managers and employees) that is separate from both the state and from its shareholders. ${ }^{24}$ The implication for CSR is that our view of CSR activities that are unrelated to the corporation, but are beneficial to society at large, should be the same as our view of such behavior by individuals: It should not be legally required, but is praiseworthy and should be encouraged when it happens. This is the view most management takes of CSR, and judging by their advertising, the view of the general public as well.

What are the implications of the real view for corporate strategic tax behavior? Judge Learned Hand famously stated in 1935 that there is "not even a patriotic duty" for citizens to pay their taxes; instead, it is the state's obligation to force them to do so. But even if that statement could be taken literally in 1935 (and there are grounds to doubt that Hand meant it seriously), it certainly cannot be applied in the post-World War II environment, in which the obligation to pay the income tax was shifted from the rich to the middle class. ${ }^{25}$ While much of the success of the US in collecting the income tax stems from its sophisticated use of withholding and information reporting, it is by no means true that nobody pays taxes voluntarily. If that were the case, the estimates for compliance in the absence of withholding or information reporting would be far below $70 \%$. The US tax system could not work unless the majority of its citizens were trying to abide by the law, not evade it.

The importance of voluntary compliance can also be demonstrated by the contrast between the US and countries in which there is no tax-paying "culture". The US is far more successful in collecting the taxes due than countries like Italy or than most developing countries, where the

\footnotetext{
${ }^{24}$ As one sociologist has stated, "[t]he recurrent problem in sociology is to conceive of corporate organization, and to study it, in ways that do not anthropomorphize it and do not reduce it to the behavior of individuals or of human aggregates." Guy E. Swanson, The Tasks of Sociology, 192 Science 665 (1976). A whole branch of economic sociology centers on the study of organizations, and there are numerous books devoted to the topic. See, e.g., James D. Thompson, Organizations in Action: Social Science Bases of Administrative Theory (1967, reissued 2003); W. Richard Scott, Organizations: Rational, Natural, and Open Systems (5 ${ }^{\text {th }}$ ed. 2003); Jeffrey Pfeffer and Gerald R. Salancik, The External Control of Organizations: A Resource Dependence Perspective (1978, reissued 2003); Walter W. Powell and Paul j. DiMaggio (eds.), The New Institutionalism in Organizational Analysis (1991); Neil J. Smelser and Richard Swedberg (eds.), The Handbook of Economic Sociology (1994), especially Part II, Section C, The Sociology of Firms, Organizations, and Industry. Most of these books revolve around the study of large corporations, since these are the dominant forms of organization in this society.

${ }^{25}$ Hand's statement was dicta in the context of the most famous case shutting down an avenue of tax avoidance, Gregory v. Helvering. As Assaf Likhovski has shown, this statement (and the whole opinion) should be understood against the background of the contemporary hearings into tax evasion by rich and famous Americans such as Andrew Mellon. It seems to me that if pressed even Hand would acknowledge that the tax system could not work if everybody tried as hard as Mellon did to avoid paying their taxes. Assaf Likhovski, The Story of Gregory: How Are Tax Avoidance Cases Decided, in Steven A. Bank and Kirk J. Stark (eds.), Business Tax Stories 89 (2005).
} 
citizens indeed follow Hand's dictum (or even regard it as their patriotic duty not to pay taxes). The reason for the US' relative success, even in an era of sharp cutbacks in IRS audit and enforcement activity, is that most US citizens do regard it as their duty to try to comply with the tax law. That is also the reason why the US can depend on most residents filing a tax return and self-assessing their tax liability every April 15, even though the refund they typically get is without interest and means that they have been giving the government an interest-free loan.

In general, the modern literature on tax enforcement assumes that there exists an "enforcement pyramid". ${ }^{26}$ At the bottom are the majority of citizens whose inclination is to try to comply with the tax law. As you go up the pyramid, the appetite for avoidance increases and the number of citizens decreases, and the type of enforcement changes from cooperation and the provision of information to increasingly harsher enforcement measures. Where the pyramid is reversed and most citizens do not cooperate, enforcement fails. In that way tax law is no different than other laws: A modern state cannot exist unless most citizens could be expected to comply with the law most of the time.

From that perspective, if the real view of the corporation is the correct one, the implication is that the corporation should behave like an ordinary citizen: It should try to comply with the tax law to the best of its ability. Thus, it is legitimate for corporations to try to minimize taxes paid on ordinary business transactions, but it is not legitimate to engage deliberately in strategic tax behavior designed solely to minimize its taxes. As stated above, while this line is difficult for the government or a court to draw from the outside, it is not so hard to discern from the perspective of the corporation.

Strangely from today's perspective, this was in fact the attitude that most corporations took to tax compliance before the 1990s. The tax function was not viewed as a profit center, and while corporations tried to minimize tax costs, large publicly held corporations did not engage in tax shelters (and were in fact quite conservative in tax matters). It was part of the corporation's general responsibility to society to pay its taxes, just like it is part of an individual's responsibility, and under the real view CSR is generally legitimate even if there is no connection between the uses of the funds and the corporation's own activities.

This attitude changed by the mid 1990s, and today major corporations like General Electric or Colgate Palmolive have lost important tax shelter cases. ${ }^{27}$ Presumably, this shift in attitude was accompanied by a shift in the corporation's view of itself, as the aggregate view came to dominate the discussion and shareholder profit maximization became the sole legitimate goal of corporate activity. To this view, which poses the hardest challenge to CSR, we can now turn.

\footnotetext{
${ }^{26}$ John Braithwaite, Restorative Justice and Responsive Regulation (2003).

${ }^{27}$ ACM, supra; Coltec v. US, 454 F.3d 1340 (Fed. Cir. 2006).
} 


\section{9] TAXATION, Corporate SOCIAL Responsibility AND tHe BUSINESS ENTERPRISE 13}

\section{The Aggregate View.}

How does strategic tax behavior appear from the aggregate perspective on the corporation? From this point of view, the sole legitimate function of the corporation is shareholder profit maximization, and any CSR activity that is not related to long-term profit maximization is an illegitimate "tax" imposed by management on the shareholders, without the accompanying democratic accountability.

It is easy to see how this view can lead to strategic tax behavior. If tax is considered a cost like any other cost imposed on the corporation, it behooves the management to try to minimize this cost, or even turn it into a profit. Thus, the goal of shareholder profit maximization can naturally lead to corporations trying to minimize taxes and thus enhance earnings per share.

In the early 1990s, two factors led an increasing number of corporations to adopt this view. First, management compensation was linked to earnings per share via stock options, and although this led to abuses in some cases (even leading to corporations like Enron paying additional taxes on fictitious earnings), in most cases the mechanism worked properly, inducing management to focus exclusively on increasing earnings per share. Second, consolidation in the accounting field led the "Big Four" accounting firms to try to move beyond their traditional audit functions to devising tax strategies to be sold to individual corporate clients.

Increasing competition among corporations and increasing pressure on top management to deliver higher EPS explains the rest. Once some firms adopted aggressive tax strategies and saw their effective global tax rate plunge and their EPS increase, management in other firms came under pressure to deliver similar results. It became commonplace for the CEO and CFO, who never bothered to look at a lowly cost center like taxes before, to summon the Tax Director and require an explanation why their global effective tax rate was several percentage points higher than the competition. The Tax Director, who was already under pressure from the accounting firms to try out novel tax strategies, usually succumbed. Thus a significant number of conservative firms came to adopt aggressive tax strategies. The rhetoric of shareholder profit maximization came to provide a convenient cover and rationalization for this activity.

A good example of the spread of this type of strategic tax behavior is the saga of inversion transactions. Before 1997, most corporate managers assumed that shareholders would not tolerate a publicly traded US corporation reincorporating in Bermuda, despite the fact that such transactions could significantly reduce the overall effective tax rate. However, after Tyco inverted in 1997 and its stock price went up, there was increased pressure on competitors, resulting in about 15 more inversions. This wave only stopped after September 11, 2001, when public outcry against "unpatriotic" corporations and ensuing changes to the tax law blocked the phenomenon, at least temporarily. The inversions were defended in the name of shareholder 
profit maximization, even though as Desai has shown they may also have made it easier to fudge corporate accounts and harm shareholders. ${ }^{28}$

What is wrong with reducing taxes as a way of maximizing shareholder returns? The basic problem is that under the aggregate view most CSR activities are illegitimate. This necessarily means that they devolve upon the state, which is supposed to use its legitimate taxing function (unlike the illegitimate tax imposed by management upon the shareholders if the corporation engages in CSR) to raise money to fulfill these obligations. ${ }^{29}$ But if all corporations engage in strategic tax behavior, the state may not be able to raise sufficient money to fulfill its exclusive social responsibility functions.

It will immediately be argued that this scenario is unrealistic: since in OECD member countries the corporate tax amounts to less than $10 \%$ of total tax revenue, the state can replace the lost revenue from corporate tax avoidance by raising other taxes. But even if one sets aside issues of distribution and fairness (lowering taxes on capital usually means higher taxes on labor), this answer is inadequate for three reasons. First, there may be political constraints to raising other taxes; especially in the US context it seems glib to say that politicians could respond to a decline in the corporate tax by raising individual tax rates. Second, individual tax rates may already be set so high that it becomes highly inefficient and potentially counter-productive to raise them further. If individual rates are set very high, there will be an impact on both the labor/leisure trade-off and on the willingness of individuals to pay taxes, on which the system depends. Finally, in many non-OECD countries, as well as in some OECD members like Japan, the corporate tax amounts to a far higher percentage of total revenues. It has been shown that tax competition, which is itself a form of strategic tax behavior, has resulted in significant declines in tax revenues in developing countries, which have not been offset by tax increases elsewhere. ${ }^{30}$

It can also be argued that strategic tax behavior by corporations is positive in situations where the government is ineffective or corrupt, and therefore the funds can be put to better use in the private sector. This is precisely the reason that under the real view CSR is acceptable, because in many situations corporations are better situated than the government to address social problems. But this argument cannot be made under the aggregate view, because under that view almost all CSR is illegitimate and solving social problems is the exclusive responsibility of the government.

Thus, it seems to me that there is an internal contradiction in Friedman's argument, which the corporate tax shelter wave of the 1990s has brought out. If the sole function of corporations is profit maximization, it seems to follow that corporations should maximize profits by minimizing their taxes. But if all corporations avoid paying taxes, the result can be inadequate revenue for

\footnotetext{
${ }^{28}$ Mihir Desai, Earnings Management and Corporate Tax Shelters (2006).

${ }^{29}$ In developed countries, the state may delegate some of its social responsibility to the non-profit sector. But this is no solution, since under the aggregate view for-profit corporations are prohibited from donating funds to non-profits as well, unless it can be shown that such contributions enhance shareholder returns (which is doubtful). Moreover, the non-profit sector is weak or non-existent in developing countries, where the CSR issue is most acute.

${ }^{30}$ Keen and Simone, supra.
} 


\section{9] TaXation, Corporate social Responsibility and the Business ENTERPRise 15}

the government to fulfill those obligations that under the aggregate view it bears the sole responsibility for. The result would be that neither corporations nor the government can address social problems, and I do not think even Friedman would regard that outcome as desirable.

I would thus argue that even under the extreme version of the aggregate view, corporations do have an affirmative obligation to pay their taxes, so as to enable the state to carry out those functions that they are barred from pursuing since they are unrelated to the goal of shareholder profit maximization. This, in fact, can be seen as another justification of imposing tax on the corporation: Rather than bear any social responsibility, the corporation can by paying its taxes shift that responsibility to the state, where it belongs.

Thus, strategic tax behavior seems to be inconsistent with any view of the corporation. Under the artificial entity view, it undermines the constitutive relationship between the corporation and the state. Under the real view, it runs contrary to the normal obligation of citizens to comply with the law even in the absence of effective enforcement. And under the aggregate view, it is different from other forms of shareholder profit maximization in that it weakens the ability of the state to carry out those functions that the corporation is barred from pursuing. It would thus seem that whatever view management takes of its relationship to the shareholders, to society and to the state, it is never justified in pursuing tax strategies that have as their only goal minimizing the corporation's tax payments to the government.

\section{The CORPORATE TAX AND CSR FROM THE STATE's PERSPECTIVE}

From the state's perspective, is the state justified in using the corporate tax as a device to induce corporations to engage in CSR? It seems clear than a major function if the corporate tax is to regulate corporate behavior and steer it in directions that the state deems beneficial. ${ }^{31}$ But is this function justified?

As Weisbach and Nussim have shown, government faces a choice in the forms of regulation it imposes. ${ }^{32}$ It can regulate directly, or it can subsidize certain activities directly, or it can subsidize indirectly via the tax system. The choice between these options depends on which is the most effective way of achieving the government's goal.

Moreover, from the government's perspective, it is clear that it can choose to perform certain activities itself, or to delegate those activities to the private sector. If the most effective way of performing social responsibilities is in the private sector, that is the option the government can

\footnotetext{
${ }^{31}$ Avi-Yonah, Corporate Tax, supra.

${ }^{32}$ David A. Weisbach and Jacob Nussim, The Integration of Tax and Spending Programs, 113 Yale L.J. 955 (2004).
} 
pursue. But in a market economy the government rarely imposes social responsibilities on private actors, and none of the views of the corporation set out above suggest that the government should impose a legal obligation on corporations to engage in CSR. The corporate tax is in general a legitimate tool for the government to incentivize private, for-profit corporations to assume certain social responsibilities.

The same conclusion can be drawn from the three perspectives on the corporation. From the artificial entity point of view, the state creates corporations precisely because it does not wish to perform certain functions itself. Those corporations are "imbued with a public purpose" and while the state cannot take them over, it can legitimately attempt to influence their behavior via the tax system. This is true even if the resulting CSR behavior would not be legitimate for the corporation to undertake on its own (because it is unrelated to its own activities): the state is still free from its perspective to try to encourage such corporate activity.

From the real entity perspective, the state can regulate corporate behavior like it regulates individual behavior, and that includes using tax expenditures. Since all forms of CSR are legitimate under the real entity view, this is the easiest case to make in justifying this form of regulation.

Finally, from the aggregate perspective, one needs again to distinguish between what CSR functions the corporation may legitimately undertake (only those that clearly result in increased shareholder profits), and those CSR activities that the state can try to incentivize corporations to undertake. The latter are broader in scope than the former. In fact, from the aggregate perspective, the state's use of tax as a regulatory tool can be seen as an attempt to align its interests with those of the shareholders by promising an increased profit (resulting from lower taxes) to shareholders from those corporations engaging in CSR activities. Given the widespread acceptance of the aggregate view from the 1990s onward, this is presumably why governments have increasingly resorted to tax incentives (as well as procurement) as a way of encouraging corporations to engage in behavior that has positive externalities, like protecting the environment.

\section{CONCLUSION}

From the corporation's perspective, it thus seems that whatever our view of the nature of the corporation, it should not be permitted to engage in strategic behavior that is designed solely to minimize its taxes. From an artificial entity perspective such behavior undermines the special bond between the state and the corporations it created. From the real entity perspective such behavior is as unacceptable as it would be if all individual citizens engaged in it. And from an aggregate perspective strategic tax behavior does not leave the state adequate revenues to fulfill the increased obligations imposed on it by forbidding corporations to engage in CSR. 


\section{9] TaXation, Corporate social Responsibility and the Business ENTERPRise 17}

From the state's perspective, it likewise appears legitimate under all three views of the corporation to use the corporate tax to steer corporate behavior in the direction of CSR. This is true even for CSR functions that the corporation may not undertake on its own, because the state can still try to encourage corporations to undertake such activities, even though it cannot force them to do so.

The problem is that as long as any CSR activity that is not related to shareholder profit maximization is deemed illegitimate if undertaken without government incentives, it seems unlikely that the government can provide sufficient incentives to align its goals with those of the shareholders. Recent experience has shown that such incentives frequently fail: For example, the temporary amnesty for repatriating corporate profits with a minimal tax rate offered for 2005 failed to induce corporations to create more jobs. Moreover, such incentives cost the government money which it could use to fulfill other social responsibilities.

Overall, while regulating corporate behavior via the tax system is a legitimate government function and a major justification for taxing corporations, it seems unlikely to lead to an ideal division of labor in addressing social problems. From the perspective of adequately addressing problems such as global warming or AIDS, it would seem that the ideal world is one in which responsibility is divided as seems best for each problem and each set of actors between the government, nonprofits, and the private sector. The government should be able to levy sufficient taxes to fulfill its share, and can also try to use both taxing and spending to induce private entities to address those problems. But for the best outcome, it seems crucial to leave corporations free like private individuals to attempt to address problems not of their own making, even if no shareholder benefit ensues. Adopting the real view of corporations, which also strikes me as the most realistic view, seems to be the best way towards this goal. ${ }^{33}$

\footnotetext{
${ }^{33}$ This still leaves unanswered the question of how to hold corporations accountable for CSR behavior. See Walsh and Avi-Yonah, supra.
} 